\title{
The properties of humic acid - cytotoxic study
}

Bratishko K.A. ${ }^{1,2}$, Buyko E.E. ${ }^{1,2}$, Ivanov V.V. ${ }^{2}$, Zykova M.V. ${ }^{2}$

${ }^{1}$ Tomsk Polytechnic University, Tomsk, Russian Federation, https://tpu.ru

${ }^{2}$ Siberian State Medical University, Tomsk, Russian Federation, https://ssmu.ru/ru/

Keywords: humic acids, cytotoxicity, MTS

doi: 10.36291/HIT.2019.bratishko.069

Humic acids (HA) are applied in alternative medicine but for their implication in the official medicine a wide-range preclinical and clinical studies are needed. Cell-viability cytotoxicity test is necessary to evaluate potential safety profile of HA and to choose the proper concentrations for the future investigations. To conduct the cytotoxicity-test the peat $\mathrm{HA}$ sample has been chosen. Isolation of HA sample was performed by the pyrophosphate $\left(\mathrm{Na}_{4} \mathrm{P}_{2} \mathrm{O}_{7}\right)$ extraction as described earlier [Zykova, 2018]. The raised pine-cotton-grass peat $(R=30-35 \%, 10-50 \mathrm{~cm})$ was taken from peat oligotrophic bog in Tomsk region (Bakchar bog area, Russia). For this sample promising antiradical and antioxidant activities have been shown during the previous studies [Zykova, 2018].

The cytotoxic properties of HA were evaluated on 3T3-I1 cell-line using the standard MTS-assay (3-(4,5-dimethylthiazol-2-yl)-5-(3-carboxymethoxyphenyl)-2-(4-sulfophenyl)$2 \mathrm{H}$-tetrazolium). MTS-assay was performed after achieving $100 \%$ confluence of cells using the CellTiter $96 \AA$ Aqueous Cell Proliferation Assay (Promega). Briefly, DMEM/F12 (100 $\mu$ l) was supplemented with MTS solution $20 \mu \mathrm{l} /$ well, incubated for $1 \mathrm{~h}$, and then the absorbance was recorded at $490 \mathrm{~nm}$ with a 96-well plate reader Sunrise RC4 (Tecan).

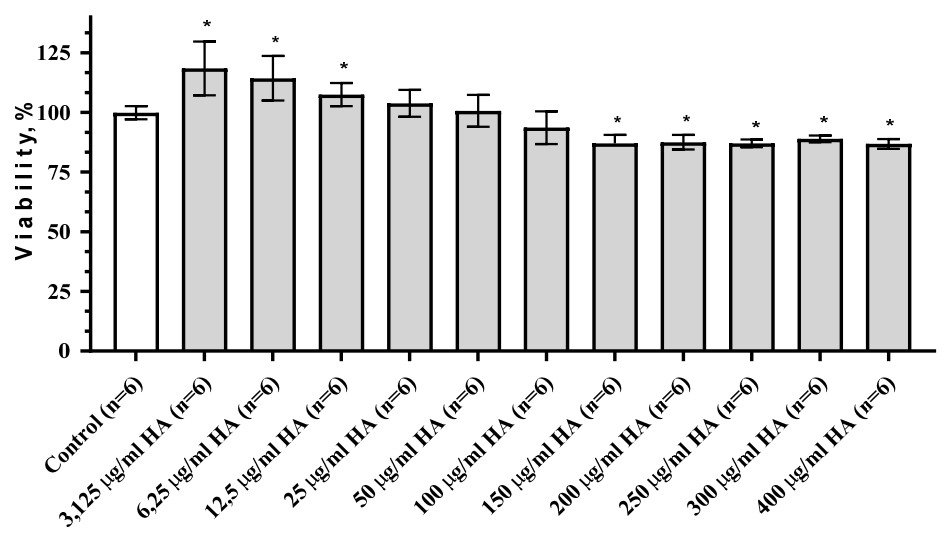

Figure 1. Viability test of HA with MTS (3T3-L1, $24 \mathrm{~h}$ of incubation). Viability is expressed as $\%$ of control (mean). The results are given as the mean $\pm S D(n=6) .{ }^{*}$ indicates a significant difference (multiple t-test) from control $(p<0.05)$.

Figure 1 shows the results of a cell mitochondrial activity viability test (MTS-test) after $24 \mathrm{~h}$ of incubation of 3T3-L1 fibroblastic cells with eleven different concentrations of HA from 3.125 to $400 \mu \mathrm{g} / \mathrm{ml}$. At 25, 50 and $100 \mu \mathrm{g} / \mathrm{ml} \mathrm{HA}$ there was no influence on the cell viability. However, a concentration-dependent toxic effect of HA was revealed on the cells cultivated with the $150-400 \mu \mathrm{g} / \mathrm{ml} \mathrm{HA}$ (for 13.0, 12.5, 12.9, 11.05, $11.2 \%$ respectively). Alternatively, cell viability was increased in presence of $3.125,6.25,12.5 \mu \mathrm{g} / \mathrm{ml} \mathrm{HA}$ (for $18.5,14.3,7.5 \%$ respectively). This pronounced effect may have been caused by the increasing of cell proliferation at less concentrations of HA. The cytotoxicity at the higher doses of HA can be explained by the osmotic effect and ability of HA to penetrate nuclei and to influence on the DNA binding affinity of the transcriptional factors [Yang et al., 2002]. Eventually, HA doesn`t demonstrate strong cytotoxic properties and allows to conduct investigations in wide range of concentrations. 